\title{
Human Capital: Key Driver towards Business Success
}

\author{
Zairul Nurshazana Zainuddin1, Suzana Sulaiman¹, Nurul Ezhawati Abdul Latif1, Mahfuzah Ahmad² \\ ${ }^{1}$ Faculty of Accountancy, Universiti Teknologi MARA, Shah Alam, 40450 Shah Alam, Selangor, Malaysia \\ ${ }^{2}$ Faculty of Accountancy, Universiti Teknologi MARA, Tapah, 35400 Tapah Road, Selangor, Perak, Malaysia \\ zairul2384@ uitm.edu.my; suzana1110@ uitm.edu.my; nurulezhawati@uitm.edu.my; mahfuzah4149@uitm.edu.my \\ Tel: +60125093979
}

\begin{abstract}
A company is a reflection of its people; human capital in recent years is believed to be a key business success factor. Limited researches in Malaysia on valuing human capital and its contribution motivate the study to be conducted. The case study method is used, with two Malaysian companies awarded as the Best Employers in recent years. The study proved that by having committed people in the companies and by responding to employee needs, it is a sign that companies are concerned with their personal and career life. Indirectly instill motivation among employees to drive towards business success together.
\end{abstract}

Keywords: Human Capital; Business Success; Case study; Malaysia

eISSN: 2398-4287@ 2020. The Authors. Published for AMER ABRA cE-Bsby e-International Publishing House, Ltd., UK. This is an open access article under the CC BYNC-ND license (http://creativecommons.org/licenses/by-nc-nd/4.0/). Peer-review under responsibility of AMER (Association of Malaysian Environment-Behaviour Researchers), ABRA (Association of Behavioural Researchers on Asians) and cE-Bs (Centre for Environment-Behaviour Studies), Faculty of Architecture, Planning \& Surveying, Universiti Teknologi MARA, Malaysia. DOI: https://doi.org/10.21834/ebpj.v5iSI3.2528

\subsection{Introduction}

The significance of human capital in today's hyper-competitive environment is tremendous and undoubted (Liepe \& Sakalas, 2014). Leaders and employees that make up an organization's human capital are critical to its success (Dias, 2017). According to Hitt and Duane (2002), people mean everything, and human capital is the most important capital. Creating a sustainable business is not merely environmental protection; an organization needs to ensure a balance between economic, environmental and social goals (Zainuddin et al., 2017). A successful organization is based on a sound assessment of the ability of the individuals and the way to exercise their functions efficiently, effectively and sustainably (Gashi et al., 2017). Because human capital is an intangible asset, assigning value to human capital is a perennial challenge (Leddy, 2017). Elias and Scarbrough (2006) suggested that the importance of the human capital concept and its measurement should be based on the relationship between the contribution of employees and the competitive performance of the business. There are no generally accepted standards for measuring the value of people, unlike the readily available tools for quantifying the value of tangible assets (Leddy, 2017). Previous definitions of human capital are primarily look in terms of economic worth and the potential yields derived from investing in such capital. The latest developments in human capital research, however, adopt a more holistic and inclusive understanding of the concept that looks beyond humans as an economic aggregate but considers a broad spectrum of variables, such as subjective wellbeing, happiness, intellect, spirituality and dignity (Wan Mansor, 2017). A study done by Lynn et al. (2010) found that investors indicated that it is important to disclose specific human capital measures such as staff satisfaction index, staff capacity, motivational index, workforce stability, and workforce competency profile.

eISSN: 2398-4287C 2020. The Authors. Published for AMER ABRA cE-Bs by e-International Publishing House, Ltd., UK. This is an open access article under the CC BYNC-ND license (http://creativecommons.org/licenses/by-nc-nd/4.0/). Peer-review under responsibility of AMER (Association of Malaysian Environment-Behaviour Researchers), ABRA (Association of Behavioural Researchers on Asians) and cE-Bs (Centre for Environment-Behaviour Studies), Faculty of Architecture, Planning \& Surveying, Universiti Teknologi MARA, Malaysia.

DOI: https://doi.org/10.21834/ebpj.v5iSI3.2528 


\subsection{Literature Review}

The human capital is an integral part of any company and contributes to business success. Human capital plays a vital role in wealth success and a significant source of competitive advantage in business (Memon et al., 2009). The concept of human resources is transformed into social capital as an outcome of globalization and corporate sustainability (Dash \& Agarwal, 2012). Economist Theodore Schultz invented the term human capital in the 1960s believed human capital was like any other type of capital; invested through education, training and enhanced benefits that lead to an improvement in the quality and level of production. Alternatively, human capital is a collection of traits such as all the knowledge, talents, skills, abilities, experience, intelligence, training, judgment, and wisdom possessed individually and collectively by individuals in a population (Investopedia, 2018). Knowledge sharing practices are found to be able to encourage and facilitate knowledge sharing. They have a positive relationship with human capital (employee competencies), which is hypothesized to have a positive connection with the performance of companies (Hsu, 2008). In the globalization era, a more knowledgeable human is needed to gain better economic growth in the future (Islam et al., 2016). The results of successful human capital development will not be seen in an instant, but rather over some time (Mohamad Rusli \& Hamid, 2014). There is a firm belief that human capital is one of the sine-qua-non assets and most valuable assets to achieve competitive advantage (Joarder et al., 2015). The prominent impact of human capital as the most important part of intangible assets needs to be discussed; to provide more useful information to top management in planning business success. Therefore, the study aims to examine the contributions of human capital as part of intangible assets towards business success. The next section addresses the research method employed in this study. The remainder of the paper is the main findings of the study. Lastly, a concluding part provides the contribution, limitation, and recommendation for future research.

\subsection{Methodology}

The study adopts a qualitative method through case studies, in exploring how Malaysian companies define valuable human capital and the contribution of the human capital towards business success. This approach also provides first-hand information on identifying the expected skills and competencies required by the Malaysian organizations, defined as valuable human capital. The companies selected for the study were awarded as among the Best Employers year 2017 in Malaysia. The companies are the leading player in the industry and able to represent their respective sectors. Contacts developed through previous research and personal industry linkages. The research was conducted based on a few stages:

Stage 1 - A thorough review of the literature on human capital and intangible assets.

Stage 2 - Case study method was adopted to answer questions such as who, what, why and how being asked to gain insights on the contributions of human capital as part of intangible assets towards business success. An initial semi-structured draft questionnaire was prepared.

Stage 3 - The draft questionnaire was developed based on the literature review. Prior permission was obtained from the selected companies.

Stage 4 - Conduct interviews on two identified Malaysian companies, selected based on its previous achievement as the best employer and suitability to this project. The companies represent their business success and awarded as the best employer in recent years. The respondents were selected based on their experiences and significant involvement in valuing human capital and planning for business success.

Stage 5- Analyze the data collected and summarize the findings.

A series of semi-structured interviews were conducted on two Malaysian companies. Face-to-face interviews with the key personnel formed essential sources of information for this study. The companies were identified as Company A and Company B for confidentiality reason, as defined in Table 1:

Table 1. Background of companies

\begin{tabular}{|c|c|c|}
\hline & Company A & Company B \\
\hline Size & Large listed & Large listed \\
\hline Core activities & $\begin{array}{l}\text { Company A has blazed a trail within } \\
\text { the healthcare industry as a provider } \\
\text { of quality products and services. } \\
\text { Listed on the Main Board of Bursa } \\
\text { Malaysia and has established itself as } \\
\text { a leader in the local market, the } \\
\text { company also has a growing global } \\
\text { presence. As part of the drive to } \\
\text { become a total integrated healthcare } \\
\text { solutions provider, its core } \\
\text { businesses span across a broad }\end{array}$ & $\begin{array}{l}\text { A world-leading quick-service restaurant } \\
\text { chain with more than } 36,000 \text { restaurants } \\
\text { worldwide, serving more than } 69 \text { million } \\
\text { customers daily in over } 100 \text { countries. In } \\
\text { Malaysia, Company B serves over } 13.5 \\
\text { million customers a month in more than } \\
260 \text { restaurants nationwide. The company } \\
\text { employs more than } 12,000 \text { Malaysians in } \\
\text { its restaurants across the nation, } \\
\text { providing career, training and } \\
\text { development opportunities. }\end{array}$ \\
\hline
\end{tabular}


spectrum of the industry. The business activities include logistics and distribution, manufacturing of generic pharmaceuticals, sales, and marketing, as well as the distribution of medical products and hospital equipment. By having synergies from these activities, Company A has expanded its reach to Malaysians through the establishment of community pharmacy.

Philosophy \& The corporate philosophy is driven Mission by its motto, Passion fo Patients. Above all, the company emphasizes on delivering its promises to the clients with the highest standards of excellence, as the company seeks to create a lasting legacy of doing business with a conscience. The mission is to provide quality products and superior services by professional, committed and caring employees.
The philosophy is founded on the promise to provide Simple Easy

Enjoyment for every customer at every visit. The mission is to be a customer's favorite place and a way to eat - with inspired people who delight each customer with unmatched quality, service, cleanliness, and value every time.

Respondents are selected based on their position, experiences, contribution and their initiatives towards the improvement in human capital management within the companies as tabulated in Table 2 below:

Table 2. Profile of Respondents

\begin{tabular}{lll}
\hline Company & Current Position & Years of Working Experience \\
\hline Company A & Senior Executive, & 9years \\
& $\begin{array}{l}\text { Training and development unit, } \\
\text { Human Capital Management. }\end{array}$ \\
Company B & $\begin{array}{l}\text { Director, } \\
\text { Human Resource. }\end{array}$ & 27years \\
&
\end{tabular}

\subsection{Findings}

Company A and Company B have identified a different definition of human capital. However, both companies agreed that human capital is a valuable and vital asset. By having different measurement to value human capital, both Company $A$ and $B$ are emphasizing on the employees' productivity and performance as the main element in doing the assessment. For Company B, providing employees with a convenient workplace with flexible working hours is a crucial factor in ensuring the employees are happy to perform their daily tasks without hesitance. Indirectly it leads to better performance for the company as a whole. By providing the employees have worklife balance also contributes to the achievement of this recognition and awards given to the company. On the other hand, Company $\mathrm{A}$ also mentioned that realizing the company is dominated by the young generation known as Millennial, and there is a need for the company to manage on their path. There is a pool of more aggressive and expressive Gen $Y$, as they are too brave in giving their opinions. However, with a suitable mechanism collaborating their ideas with previous generation Gen $\mathrm{X}$, the results may turn very well for the company. It is a significant change faced by employers nowadays to ensure the value of human capital is appreciated. Company B also stated that the company values the workers as business partners. By giving opportunities for them to voice out their opinion through a survey, is an initiative by the company to promote fairness among the companies and employees need. Realizing that the company's future is a reflection of its employees' effort, the company always believed that they are valuable assets to be managed properly. Every employee is a business champion in companies. The finding is summarized based on the respondents' quotes in Table 3.

Table 3. Respondents' Quotes

\begin{tabular}{ll}
\hline Company A & Company B \\
\hline How do you define Human Capital? & \\
Do you think human capital is a vital asset in your company? \\
How your company measures the value of human capital? \\
\hline "Human capital can be defined as a "Human capital is a very significant asset \\
"one-stop center" to fulfilling needs by $\quad$ for the company instead of the current \\
employees such as any claim, salary, & state of financial value in the company. \\
bonus, performance, help or incentive & Human capital, with their knowledge, skills \\
benefits. Human capital is essential, & and working experience, is an enabler for \\
and the main asset of the company to & the company to grow. For this purpose, \\
sustain. The company measures and & the people who worked for the company \\
values human capital through the & are defined as human capital. Without \\
Performance Measurement System & valuable human capital, the company has \\
(PMS)." & a barrier to expand and grow the business
\end{tabular}




regardless of a lot of human resources to
run the business. The company values
human capital based on their productivity
and performance through a performance-
based system, especially for reward
promotion incentive. The company is not
only relying and measuring based on a
dollar-cost to one person, as per se."

Being the Best employer recently, in your opinion, how an employer can motivate the employees to strive together towards business success?

"Being an employer, one of the things that we can motivate our employees by giving them a few unique benefits. For example, for employees whose wearing a uniform, they are provided with laundry allowance, which not all employers can provide for."

\begin{abstract}
The journey to becoming the best employer is very long for Company $B$. The company takes a few years to take part in the best employer competition after due consideration. To be among the Best Employer, we focus on a holistic view at all angles. The company tries the best to balance the employee task with their needs. For having a "win-win" situation, the company needs to balance the two different needs; the company and employee needs. The company has an effort to consider the view from employee perspectives by initiating a survey at least once a year. The company will highlight the need for employees to make their career and personal life better. By responding to their opinions, the people will feel appreciated, thus working together to build the company to another level. Meaning that the company achieves what they want, the employee also realized what they want in term of their career as well as personal. For example, the company introduces a flexible working hour, as early as 8.30 in the morning and later than 9.00 in the morning to cater to the different needs of different employees.

This is one of our initiatives to make the career and personal life employees are well balanced."
\end{abstract}

As we know, human capital recently plays important roles in striking business success and contributes significant value to the intangible asset of your company. Do you agree with this statement?

What do you see the most significant changes in their roles and value of human capital in the future compared to the past?

"Human capital plays a vital role in "Human capital is no longer classified as a
the company's business success as worker in Company B. They are now
the company is seeking the best considered as the company's business
talent to join the company to give partners. They are not just completing
fresh ideas that contribute to their task but also contributing in the way
improved performance. With of working together with management in
understanding, every people has their driving towards business success. They
ability and unique, the company also play a significant role in
welcomes talents who are unique in accomplishing the company's strategy;
their way and open up opportunities thus, they have an additional role than the
to share new ideas for the betterment assigned daily task. This is a significant
of the company. Right talents can be change in their roles comparing to the
seen from the way they express their past. At the end of the day, if the business
commitment to the company's future. grows, they will grow together with the
Being aware the young generation is company and enjoying the benefits
millennial who are mixing between gained."
millennial who are mixing between the gen $Y$ and the gen $X$; the company can see significant changes in their roles in the future comparing to the past. The new generation nowadays known as Gen $Y$ has different ideas, compared to Gen $X$. They are more expressive, outspoken and brave in giving ideas. The way they think is quite different from the older generation. By complementing
"Human capital is no longer classified as a Company B. They are now partners. They are not just completing task but also contributing in the way accomplishing the company's strategy thus, they have an additional role than the past. At the end of the day, if the business company and enjoying the benefits gained." 
and supplementing both ideas from two different generations, this gives a significant contribution to the company, resulting in fantastic ideas for the benefit of the company."

\subsection{Conclusion \& Recommendations}

In conclusion, both Company A and Company B highlighted that listening to the employee needs and providing them with special benefits are the main factor the companies been awarded as among the Best Employers in Malaysia for the year 2017. This is due to the fact when employees are feeling appreciated and have a sense of belongingness; they feel motivated to go to work. Indirectly will contribute to the greater success to the companies. The study also proved that human capital plays a significant role in influencing the companies' current and future performance. According to the International Integrated Reporting Committee, IIRC (2016), the needs of human capital change over time as markets, technology and societies develop. Managing and reporting on human capital is challenging but vital to help companies create and maximize value. Human capital gives a critical impact in key business areas such as driving customer satisfaction, product or service innovation, growth and overall profitability (Leddy, 2017). People may contribute to business success by way of their expertise, efficiency, productivity, intellectual assets and leadership skills (Mention, 2012). The company also needs to respond to flexibility by changing its culture to one in which there is a greater emphasis on people and processes so that the decisions can be made more efficiently (Kotter \& Schlesinger, 2008). There is a significant relationship between human values and conditions for business success (Mcbain, 2005). There is limited study in the research area in Malaysia. The findings from the study can be shared as best practices on valuing human capital among Malaysian companies, as the companies selected in the study were being awarded as Best Employers in recent years. It will provide sources of valuable information for Malaysian companies to enhance their human capital initiatives and sustain business in the long run. The findings may also be of value in informing the companies' leaders; the relationship between human capital and business success. A similar study is recommended to be extended to other companies from different countries for future research.

\section{Acknowledgment}

The authors gratefully acknowledge Universiti Teknologi MARA (UiTM) for funding the research project through the LESTARI Grant. Our appreciation also goes to the Faculty of Accountancy, Universiti Teknologi MARA for facilitating the research project.

\section{References}

Dash, S.P., \& Agarwal, V. (2012). Role of Human Capital Management in Economic Value Addition of Large-Scale Organizations: A Literature Review. International Journal of Financial Management, 45-54.

Dias, M. (2017). Human capital: developing the most overlooked asset class. Business Monthly. Article by CEO-FAPCL GROUP Email: md@fapcl.com, February 6, 2017.

Elias, J., \& Scarbrough, H. (2006). Evaluating Human Capital: An Exploratory Study of Management Practice. Human Resource Management Journal, 14 (4).

Gashi, L.M., Pozega, Z., \& Crnkokovic, B. (2017). Employees' Individual Values as a Source of Human Capital. Journal Economic Research, 30(1), $1057-1072$.

Hitt, M. A., \& Duane, R. (2002). The Essence of Strategic Leadership: Managing Human and Social Capital. Journal of Leadership \& Organizational Studies, $9,1$.

Hsu, I-C. (2008). Knowledge sharing practices as a facilitating factor for improving organizational performance through human capital: A preliminary test. Expert Systems with Applications, 35, 3, (1316).

International Integrated Reporting Committee, IIRC (2016) Creating Value the Value of Human Capital Reporting, 3-29.

Investopedia (2018). Human Capital. Accessed online via Google.com, September 4, 2018.

Islam, R., Abdul Ghani, A.B., Kusuma, B., \& Theseira B.B. (2016). Education and Human Capital Effect on Malaysian Economic Growth. International Journal of Economics and Financial Issues, 2016, 6(4), 1722-1728. ISSN: 2146-4138.

Joarder, M.H.R., Subhan, M., Ghani, A.B.A., Islam, R. (2015), Pay, security, support and intention to quit relationship among academics in developing economy. Investment Management and Financial Innovations, 12(3), 190-199.

Kotter, J.P., \& Schlesinger, A. (2008). Choosing Strategies for Change. Harvard Business Review, July-August 2008 Issue.

Leddy, C., (2017). The Value of Human Capital: Measuring your Most Important Assets. Accessed online via Forbes.com, 15 November 2017.

Liepe, Z., \& Sakalas, A. (2014). Evaluation of human capital role in the value creation process. Procedia - Social and Behavioral Sciences, 156,78 - 82.

Lynn L. K. Lim, Christopher C. A. Chan \& Peter Dallimore (2010). Perceptions of Human Capital Measures: From Corporate Executives and Investors. Journal of Business and Psychology. 25, 4, (673).

Mcbain, R. (2005). Appreciating the Value of Human and Social Capital. Henley Manager Update. 16, 3 (1). 
Memon, M.A., Mangi, R.A., \& Rohra, C.L. (2009). Human Capital a Source of Competitive Advantage. Australian Journal of Basic and Applied Sciences, 3(4): 41824189, ISSN 1991- 8178

Mention, A.L. (2012). Intellectual Capital, Innovation and Performance: a Systematic Review of the Literature. Business and Economic Research ISSN 2162-4860 $2012,2(1)$.

Mohamad Rusli, N.A., \& Hamid, Z. (2014). Human capital and economic growth: Empirical Evidence from Malaysia. Recent Trends in Social and Behavior Sciences Lumban Gaol et al. (Eds). Taylor \& Francis Group, London, ISBN 978-1-138-00121-3.

Wan Mansor, W.N. (2017). A model of human capital development. New Straits Times, September 16, 2017 @ 11:52am.

Zainuddin, Z.N., Sulaiman, S., Abdul Hamid, S. F., Kasim, E.S., \& Md Zain, N. (2017). Ethical Champion towards Business Sustainability: Malaysia evidence. 4th International Conference on Social Science (CSSR 2017), Adya Hotel, Langkawi Kedah, Malaysia. 